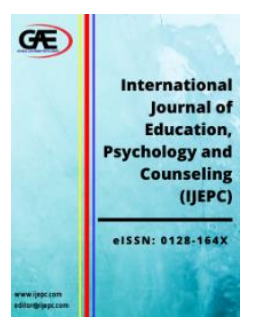

International Journal of Education, Psychology and Counselling (IJEPC)

Journal Website: http://ijepc.com/ eISSN: 0128-164X

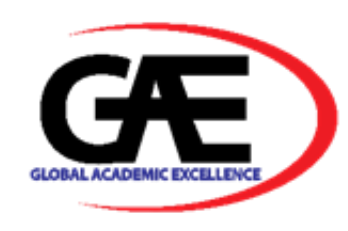

\title{
IMPLEMENTATION OF PROFESSIONAL LEARNING COMMUNITY AMONG TEACHERS IN MALAYSIA
}

\author{
Mohd Aizat Abu Hassan ${ }^{1 *}$, Kamarudin Musa², Zahari Hashim ${ }^{3}$, Nurul Fadly Habidin ${ }^{4}$
}

1 Faculty Of Management And Economy, Universiti Pendidikan Sultan Idris, Malaysia

Email: q000624@siswa.upsi.edu.my

2 Faculty Of Management And Economy, Universiti Pendidikan Sultan Idris, Malaysia

Faculty Of Management And Economy, Universiti Pendidikan Sultan Idris, Malaysia

Faculty Of Management And Economy, Universiti Pendidikan Sultan Idris, Malaysia

Corresponding Author

\section{Article Info:}

\section{Article history:}

Received date: 11.02 .2020

Revised date: 17.02 .2020

Accepted date: 18.02 .2020

Published date: 15.03 .2020

To cite this document:

Hassan, M. A. A., Musa, K., Hashim, Z., \& Habidin, N. F. (2020).

Implementation of Professional

Learning Community among

Teachers in Malaysia. International

Journal of Education, Psychology and Counseling, 5 (34), 137-146.

DOI: $10.35631 / \mathrm{IJEPC} .5340011$

\begin{abstract}
:
This study conducted to identify the level of implementation of the Professional Learning Community (PLC) among teachers in Malaysia. Respondents of the study consisted of 419 randomly selected school teachers. Overall, the professional learning community among teachers in Malaysia is still at a moderate level. This finding will help the relevant parties to find solutions to help improve the level of implementation of Professional Learning Communities among teachers in Malaysia.
\end{abstract}

Keywords:

Professional Learning Community, Malaysia Education Development Plan, Educational Transformation

\section{Introduction}

Various reforms that have links with knowledge and information boom are becoming trends in the benchmarking of National Education Quality in Malaysia. This change is so compelling that demanding that every individual in the field of education do a paradigm shift in addition to streamlining their knowledge and professional skills. Hence, to produce students with knowledge and skills, some things need to be addressed by all parties. Every schooler should develop individual capacity, especially teachers who are directly involved in making a change 
(Zuraidah, 2010). The Malaysia Education Blueprint 2013 - 2025 has recommended the PLC as a tool that can help improve teacher professionalism through knowledge sharing within the community of teachers and staff within the school. PLC culture in schools is a continuous effort that can help teachers to improve their teaching (pedagogy) effectively and continuously (KPM, 2013) Root on learning communities is an adaptation of the concept of organisational learning introduced by Senge (1990). Whereas, the learning community involves interpersonal relationships such as the warmth shown in a family, a neighbour or any group that has a close relationship and tends to be a family with pure intentions (Senge, 1990).

Teachers relate to each other in carrying out teaching reflection. In other words, teacher practice shared with their colleagues through working in a team, collaborative and have the same norms and values. However, teachers are tended to work independently and rarely practice the sharing and sharing of learning experiences with their colleagues. According to Stegall (2011), teachers tend to practice the traditional way of working alone, and this can affect the level of selfefficacy of teachers. The school administrator should make sure that initiatives start from below and from above as the teacher who will determine a change initiative is permanent. Therefore, principals' support is essential to attracting teachers to be involved in school change. To ensure that this is the case, this. School teachers need to be nurtured with the learning culture together. According to Zuraidah (2010), to achieve this goal, school principals cannot rule out the importance of learning among teachers.

Hence, the principals' support for human capital development should occur holistically aimed at the development of knowledge, skills, intellectuals, and progressive attitudes towards ethical and moral values. The teachers at the school are closer to the pupils and understand the learning needs of their students. Therefore, PLC's practice can fill the needs of education leaders to change the teaching and learning behaviours of teachers. PLC is a process of human capital development that can teach teachers, classroom management, communication and more. It demonstrates the willingness of teachers to learn as well as assist in improving a school. All schoolchildren work together and collaborate to ensure that their students are learning at the same time, forming PLC practices in schools.

\section{Problem Statement}

The 2013-2025 Education Development Plan (MEDP) in the process of transforming education that involves large-scale changes requires teachers to be agents of change. Teachers are one of the key factors contributing to the current review, among which is the dissemination of knowledge among teachers, through the professional learning community (PLC) as proposed in MEDP. While teachers are in an ever-changing dynamic environment, the phase of PLC implementation and the factors that influence them to remain a question mark, according to Stegall (2011), teachers tend to adopt traditional methods only, and this may change the level of PLC implementation in schools. The study of the level of implementation of PLCs in Malaysian schools is lacking, so this study wants to bridge the gap to see the level of implementation in schools.

\section{Purpose of The Study}

This study was carried out with the aim of identifying the level of implementation and factors affecting the application of the professional learning community (PLC) in Malaysia. 


\section{Research Objective}

1. Identify the level of implementation of the professional learning community among teachers in Malaysia.

2. Identifying factors that influence the implementation of professional learning communities among teachers in Malaysia.

\section{Research Question}

1. What is the level of implementation of the professional learning community among teachers in Malaysia?

2. What are the most factors that influence the implementation of professional learning communities among teachers in Malaysia?

\section{Conceptual Framework}

The formation of the primary content or process for this study is based on three factors that influence the implementation of the PLC found as a result of the benchmark practice by Kruse, Louis and Bryk (1994). These three factors are critical elements, human resources, and structural conditions in your school.

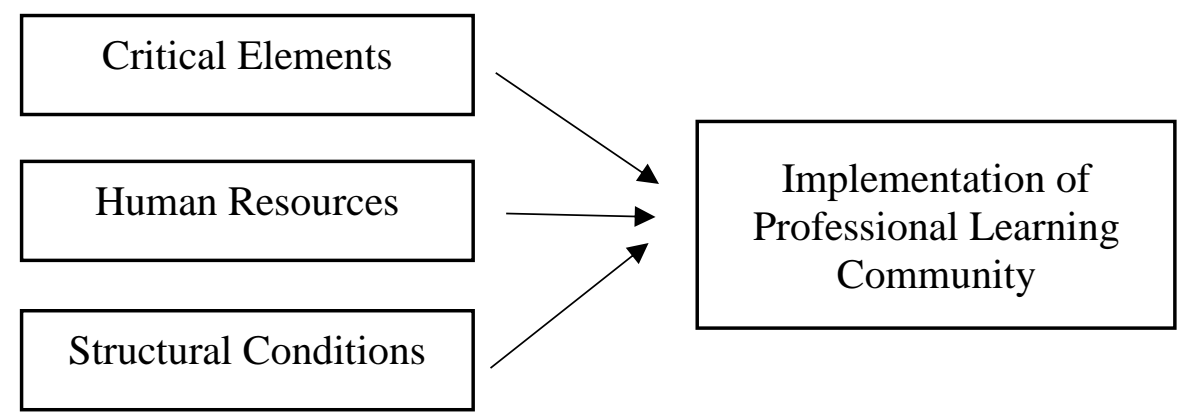

Figure 1: Conceptual Framework

Table 1: The conceptual framework of Kruse, Louis and Bryk's (1995) PLC

\begin{tabular}{|c|c|}
\hline \multicolumn{2}{|r|}{ Formulation Theory } \\
\hline Factors & Elements \\
\hline Critical & - Effective dialogue \\
\hline Elements & $\begin{array}{l}\text { - A collective focus on student learning } \\
\text { - Classes are open for other teachers to observe } \\
\text { - Collaboration practice } \\
\text { - Sharing values and habits }\end{array}$ \\
\hline Human & - Willingness to change. \\
\hline Resources & $\begin{array}{ll}\text { - } & \text { Trust and respect. } \\
\text { - } & \text { Supportive leadership. } \\
\text { - } & \text { Socialization. } \\
\text { - } & \text { Cognitive skills. }\end{array}$ \\
\hline $\begin{array}{l}\text { Structural } \\
\text { Conditions }\end{array}$ & $\begin{array}{l}\text { - } \text { Meet and talk time } \\
\text { - } \quad \text { Put teachers close to each other } \\
\text { - } \quad \text { Don't rely on school administrators } \\
\text { - } \quad \text { Empower teachers and schools }\end{array}$ \\
\hline
\end{tabular}




\section{Literature Review}

The term PLC emerged from Organization Theories and same term appeared in educational research in the early 1960's when researchers introduced the concept as an alternative to reduce teacher isolation culture. After the PLC concept introduced in the field of foreign education, this concept widely accepted among educators. Research has shown that the school, which is a bureaucratic organisation, is transformed into a school which practices the PLC's work that emphasises collaboration between colleagues (Dufour \& Eaker, 1998). Various definitions give on PLC. It follows multiple perspectives and perspectives. An easy concept to understand PLC's is a community in schools that is human, collectively working together and sharing skills, expertise and knowledge to achieve the same goals. According to Zuraidah (2010), PLC's defined as giving birth to a learning culture to learn. Teachers learn, students also learn. All communities at school are learning together. Some scholars have professional meanings as people who are continually learning to adapt to the ever-changing changes. Carla (2009) finds teachers in schools that practice PLC's can help to change teaching practices and focus on active student learning and teaching needs. With this, PLC concerned with developing a new culture in schools that are learning the culture and continuously learning to grow in tandem with current changes. It coincides with Scherer's (2009) view quoting Hord's words that today's PLC is the most robust strategy and structure in the effort to improve and improve school effectiveness. PLC was at a high level among respondents. However, the relationship between their dimensions was weak but are significant (Aziah, Loh dan Abdul Ghani, 2015)

Senge (1990) describes learning as a member of an organisation attempts to make the desired decision through learning. Senge (1990) has outlined five disciplines to create a learning organisation, namely thinking system, personal mastery, mental model, sharing of opinions and learning teams. Based on these five disciplines, Louis, Kruse and Bryk (1995) began to develop PLC's. For example, the instructional teacher provides lesson plans, discussion of teaching and observation matters. Things that teachers do not do in the classroom are essential for school re-culture. Their study focuses on the formation of communities where collaborative teachers influenced by peer feedback about the tasks they have done. The central principle of PLC is focusing on student learning. Hord (1997) explains that PLC'S referred to learning professionally and together for the improvement of pupils' education. Hord's research focuses on the critical components of the PLC, which are collaborative teachers. Hord stressed that teachers working collaboratively in PLC'S could avoid working individually. Furthermore, teachers can be committed to each other and share knowledge. For students and teachers to benefit from empowerment, a professional community must develop among teachers, one committed to a fundamental change in teaching practices (Kruse, Louis \& Bryk, 1994).

According to Nolan (2009), schools operating with PLC practice encourage learning in the community. According to the PLC Model by Hord (1997) and Hipp and Huffman (2003), the dimensions of PLC are:

a) Leadership dimension of sharing and supporting shows that leadership distributed among the school children based on the values they possess and mutual trust.

b) The aspects of the benefits, mission and vision goals refer to teachers and school administrators who share their vision and work collectively to improve school activities.

c) The collective learning dimension and application illustrates the culture of learning by the team in an organisation.

d) The aspects of personal practice sharing pay attention to the observation, encouragement and sharing of large practices. 
e) The supportive dimension of the situation reflects a committed school by showing support in maintaining the school improvement process continuously.

\section{PLC's Context in Malaysian Education}

In the field of Malaysian education, the theme of the learning community or PLC has a variety of purposes. The argument is supported by Zuraidah, Rahimah and Muhammad Faizal (2014) who said that western scholars had expressed various definitions, but there is no universal definition. It is because the development of the assessment based on different contexts and perspectives, either looking at the standpoint of the continuous, reflective, collaborative, inclusive or in-depth practice of teachers in the standard practice. However, the explanation of PLC's intentions often links to collaborative practices such as community practices, community relationships, knowledge communities and learning groups. In the opinion of Zuraidah (2010), the PLC defined as giving birth to a learning culture to discover, teachers learn, students also learn, and all communities at school are learning together.

Professional teaching and learning communities include staff, students and administrators. They try to develop a curriculum and focus on students. The argument is in line with Hord \& Sommers (2008), PLC portrayed that all professionals comprising all teachers, counsellors and administrators are always involved in the ongoing PLC. All of them who are professionals in the school are monitoring each other, giving feedback, seeing each student's training and learning outcomes together, attending seminars to share practices exploring new approaches and approaches to making work teaching and learning more effectively. In summary, PLC's arise after the implementation of learning organisations. It because PLC emphasises cultural factors as a contributing factor to its ongoing and long-term application. Whereas the existence of learning organisations is subject to the structure of an organisation and the enhancement of community professionalism depends on regulatory enforcement. Furthermore, the PLC is a practice that emphasises the cumulative aspect of the community of an organisation.

\section{Research Design}

This study uses quantitative methods. Quantitative research is a statistical analysis using numerical data and objective measurement to illustrate the problem of the study with relationships, causes an impression (Ary, Jacobs, Razavieh, \& Sorensen, 2005). According to Ary et al. (2005), quantitative studies have the writing highlights, the development of instruments, data collection, data analysis and conclusions. This study uses a survey method using the questionnaire as an instrument in collecting research data. According to Gay and Air (2009), the questionnaire method is an effective way of not spending much time and spending, even allowing large amounts of data collection. This study involves teachers in Malaysian schools.

\section{Research Instrument}

Questionnaires divided into two main sections:

a) Respondent demographics

b) Professional Learning Communities based from the article "Building a Professional Community at School" by Kruse, Louis and Bryk (1994) which contain three divisions which are critical elements, human resources, and structural conditions in your school. The School Reform Initiative compiled the questionnaire. 


\section{Research Respondents}

A total of 419 of the 421,828 permanent teachers in Malaysian schools was randomly selected as respondents for the study. The size of the respondents of this study was determined based on the proportion of the study population (Krejice \& Morgan, 1970).

\section{Data Analysis}

Data obtained will be analysed using the Statistical Package for the Social Sciences (SPSS) software. SPSS is used to analyse descriptive data that is a respondent profile, and findings data, mean, standard deviation, percent. Descriptive analysis involving mean and standard deviation conducted to interpret factors that influence the level of PLC implementation in Malaysia. Factors affecting are critical elements, human resources, and structural conditions in your school. To answer the question of the first and second study What is the level of implementation of the professional learning community among teachers in Malaysia and what are the factors that influence the implementation of professional learning communities among teachers in Malaysia will be analysed and interpreted in this section. To answer the question of the study, the mean score scores, such as Table 1, are used.

\begin{tabular}{cc} 
Table 2: Scale Mean Score and Interpretation \\
\hline Mean Score & Interpretation \\
\hline $1.00-2.50$ & Low \\
$2.51-4.50$ & Moderate \\
$4.51-6.00$ & High \\
\hline
\end{tabular}

\section{Research Findings}

This section describes the results of the analysis of the study data covering respondents' profiles and findings based on research questions namely the level of implementation of the professional learning community (PLC) by teachers in schools in Malaysia.

\section{Respondents}

The population of this study involves teachers serving the Ministry of Education Malaysia (MOE), whether it is a primary school or a secondary school of 421,828 teachers. Questionnaires distributed through social websites, emails and chat applications. The number of respondents who answered the survey was 419 teachers in Malaysia. 28.2\% were male teachers (118 respondents), and the remaining 71.8\% (301 respondents) were female teachers. Respondents with diplomas are $7.1 \%$ (30 respondents), $73.0 \%$ (306 respondents) have a bachelor's degree, $19.1 \%$ (80 students) have a master's degree, and $0.7 \%$ (3 respondents) hold a doctorate. Respondents with a service life of 0 to 5 years were $27.2 \%$ (114 respondents), 6 to 10 years were $13.8 \%$ (58 respondents), and $58.9 \%$ (247 respondents) had over ten years of experience.

\section{Level of Implementation of The Professional Learning Community (IPLC)}

Descriptive analysis from table 2 will identify the level of implementation of professional learning communities among teachers in Malaysia. This is to answer the first question of what is the level of implementation of the professional learning community among teachers in Malaysia? 
Table 3: Mean Score nd Standard Deviation of IPLC

\begin{tabular}{lcc}
\hline \multicolumn{1}{c}{ Itema } & Mean & SD \\
\hline $\begin{array}{l}\text { Teachers and school staff talk to each other about the situation and the } \\
\text { challenges they face }\end{array}$ & 4.98 & 1.07 \\
$\begin{array}{l}\text { Teachers share, observe, and discuss their respective teaching methods } \\
\text { and philosophies }\end{array}$ & 4.64 & 1.09 \\
$\begin{array}{l}\text { Teachers assume that all students can study at a high level and teachers } \\
\text { can help them }\end{array}$ & 3.75 & 1.35 \\
$\begin{array}{l}\text { Teachers produce materials and activities that enhance teaching, } \\
\text { curriculum, and evaluation. }\end{array}$ & 4.75 & 1.03 \\
$\begin{array}{l}\text { Teachers shared values on critical education issues } \\
\text { Teachers take the risk of trying new techniques and ideas and learn more }\end{array}$ & 4.58 & 0.98 \\
$\begin{array}{l}\text { about their profession } \\
\text { Teachers are proud of their expertise in school as well as outside school }\end{array}$ & 4.31 & 0.99 \\
$\begin{array}{l}\text { Inside the school, there is formal way to share expertise among teachers } \\
\text { Schools focus on common goals, continuous improvement, and }\end{array}$ & 4.54 & 1.16 \\
$\begin{array}{l}\text { collaboration } \\
\text { School staffs feel that new teachers are an important and productive part }\end{array}$ & 4.69 & 1.08 \\
$\begin{array}{l}\text { of the school community } \\
\text { There is a formal process for teachers for self-esteem and self-renewal. }\end{array}$ & 3.95 & 1.11 \\
$\begin{array}{l}\text { Teachers have room or room for discussion on teaching practices } \\
\text { There are repeated formal situations where teachers can work }\end{array}$ & 4.00 & 1.26 \\
$\begin{array}{l}\text { There is an opportunity for teachers to exchange ideas between units, } \\
\text { committees, teams or others }\end{array}$ & 4.29 & 1.17 \\
Teachers have autonomous powers to make decisions about their work & 4.61 & 1.10 \\
\hline Level of implementation of the professional learning community & 3.96 & 1.27 \\
\hline
\end{tabular}

The highest mean value is the "Teachers and school staff talk to each other about the situation and the challenges they face" $(\mathrm{M}=4.98, \mathrm{SD}=1.07)$. While the lowest mean value is on the "Teachers assume that all students can study at a high level, and teachers can help them" $(\mathrm{M}=$ $3.75, \mathrm{SD}=1.35$ ). Overall, the level of implementation of professional learning communities among teachers was at a moderate level $(\mathrm{M}=4.43, \mathrm{SD}=1.14)$.

\section{The IPLC Based on Factors}

The descriptive analysis of tables 3, 4 and 5 will identify the level of implementation of professional learning communities based on three factors (critical elements, human resources, and structural conditions in your school). It to answer the second question of what is the most factors that influence the implementation of professional learning communities among teachers in Malaysia?

Table 4: Mean Score and Standard Deviation of IPLC (critical elements)

\begin{tabular}{lcc}
\hline \multicolumn{1}{c}{ Item } & Mean & SD \\
\hline $\begin{array}{l}\text { Teachers and school staff talk to each other about the situation and the } \\
\text { challenges they face }\end{array}$ & 4.98 & 1.07 \\
$\begin{array}{l}\text { Teachers share, observe, and discuss their respective teaching methods } \\
\text { and philosophies }\end{array}$ & 4.64 & 1.09 \\
$\begin{array}{l}\text { Teachers assume that all students can study at a high level and teachers } \\
\text { can help them }\end{array}$ & 3.75 & 1.35 \\
$\begin{array}{l}\text { Teachers produce materials and activities that enhance teaching, } \\
\text { curriculum, and evaluation. }\end{array}$ & 4.75 & 1.03 \\
\hline
\end{tabular}




\begin{tabular}{lcc}
\hline Teachers shared values on critical education issues & 4.58 & 0.98 \\
\hline $\begin{array}{l}\text { Level of implementation of the professional learning community } \\
\text { (critical elements) }\end{array}$ & 4.54 & 1.104 \\
\hline
\end{tabular}

Referring to table 3, the overall implementation of professional learning communities among teachers in Malaysia based on critical element factors is at a high level $(\mathrm{M}=4.54, \mathrm{SD}=1.104)$. The highest mean value is the "Teachers and school staff talk to each other about the situation and the challenges they face" $(\mathrm{M}=4.98, \mathrm{SD}=1.07)$. While the lowest mean value is on the "Teachers assume that all students can study at a high level and teachers can help them" $(\mathrm{M}=$ $3.75, \mathrm{SD}=1.03$ )

Table 5: Mean Score and Standard Deviation of IPLC (human resources)

\begin{tabular}{lcc}
\hline \multicolumn{1}{c}{ Item } & Mean & SD \\
\hline $\begin{array}{l}\text { Teachers take the risk of trying new techniques and ideas and learn more } \\
\text { about their profession }\end{array}$ & 4.76 & 0.99 \\
$\begin{array}{l}\text { Teachers are proud of their expertise in school as well as outside school } \\
\text { Inside the school, there is a formal way to share expertise among teachers }\end{array}$ & 4.31 & 1.16 \\
$\begin{array}{l}\text { Schools focus on common goals, continuous improvement, and } \\
\text { collaboration }\end{array}$ & 4.69 & 1.14 \\
$\begin{array}{l}\text { School staffs feel that new teachers are an important and productive part } \\
\text { of the school community }\end{array}$ & 4.63 & 1.11 \\
\hline $\begin{array}{l}\text { Level of implementation of the professional learning community } \\
\text { (human resources) }\end{array}$ & 4.59 & 1.096 \\
\hline
\end{tabular}

Referring to table 4, the overall implementation of the professional learning community among teachers in Malaysia based on human resources factors is at a high level $(\mathrm{M}=4.59, \mathrm{SD}=$ 1.096). The mean value of the highest averages in the item "Teachers take the risk of trying new techniques and ideas and learn more about their profession" $(\mathrm{M}=4.76, \mathrm{SD}=0.99)$. While the lowest mean value is on the "Teachers are proud of their expertise in school as well as outside school" $(\mathrm{M}=4.31, \mathrm{SD}=1.16)$.

Table 6: Mean Score and Standard Deviation of IPLC (structural conditions)

\begin{tabular}{lcc}
\hline \multicolumn{1}{c}{ Item } & Mean & SD \\
\hline There is a formal process for teachers for self-esteem and self-renewal. & 3.95 & 1.26 \\
Teachers have room or room for discussion on teaching practices & 4.00 & 1.37 \\
There are repeated formal situations where teachers can work & 4.29 & 1.17 \\
There is an opportunity for teachers to exchange ideas between units, & 4.61 & 1.10 \\
committees, teams or others & 3.96 & 1.27 \\
Teachers have autonomous powers to make decisions about their work & 4.16 & 1.23 \\
\hline Level of IPLC (structural conditions in your school)
\end{tabular}

Referring to table 5, the overall implementation of professional learning communities among teachers in Malaysia based on structural conditions is moderate $(\mathrm{M}=4.16, \mathrm{SD}=1.23)$. The highest mean value is the item "There is an opportunity for teachers to exchange ideas between units, committees, teams or others" $(M=4.29, \mathrm{SD}=1.17)$. While the lowest mean value is on the "There is a formal process for teachers for self-esteem and self-renewal." $(\mathrm{M}=3.95, \mathrm{SD}=$ 1.26). Refers to the three tables, namely table 3, 4 and 5 main factors that influence the implementation of professional learning communities among Malaysian teachers influenced by human resource factors. It is because the descriptive analysis shows the mean value, which gives a high interpretation $(\mathrm{M}=4.59, \mathrm{SD}=1.096)$.

Copyright (C) GLOBAL ACADEMIC EXCELLENCE (M) SDN BHD - All rights reserved 


\section{Discussion and Conclusion}

Overall, the professional learning community among teachers in Malaysia is still at a moderate level. It answered the question of the first study, which is the level of implementation of the professional learning community among teachers in Malaysia. Aziah, Loh and Abdul Ghani (2015) also stated that PLC was at a high level among respondents, but the relationship between their dimensions was weak but significant. Although many studies have shown that the PLC as a whole may have a positive impact on the development of the profession and the knowledge of teachers, this demonstrates various efforts to be carried out by the stakeholders. Itis to ensure PLC can be one of the methods of development of teacher knowledge as discussed in the Malaysian Education Development Plan (MEDP). The findings that answered the second question, which factors influencing the level of implementation of PLC among teachers in Malaysia, showed that human resources had the highest impact and this was in line with Novita, Kennedy \& Mudrika (2018) study which stated that human resource quality had a positive effect on organisational performance.

\section{References}

Ary, Jacobs, Razavieh, \& Sorensen. (2005), Introduction to Research in Education (7th, Seventh Edition). Wadsworth: Cengage Learning

Aziah Ismail, Loh Hooi Yen \& Abdul Ghani Kanesan Abdullah. (2017). Komuniti pembelajaran profesional dan efikasi kendiri guru sekolah menengah di Pulau Pinang. JuPiDi: Jurnal Kepimpinan Pendidikan, 2(1), 1-12. Retrieved from https://jupidi.um.edu.my/article/view/8308

Carla. (2009), Case study: Teacher perceptions of professional learning Communities in an elementary school setting. Ed. D. dissertation, Walden University, United StatesMinnesota.

Dufour, R. \& Eaker R. (1998), Professional Learning Communities at Work: Best Practices for Enhancing Student Achievement Perfect. Solution Tree.

Gay, L.R. \& Airasian (2009). Educational Research. Competencies for analysis and application (9th ed). New Jersey: Pearson Education International

Hipp, K. \& Huffman J.B. (2010), Demystifying Professional Learning Communities: School Leadership at Its Best . R\&L Education.

Hord, S. M., \& Sommers, W. A. (2008). Leading professional learning communities: Voices from research and practice. Thousand Oaks, CA: Corwin Press.

Hord, S.M. 1997. Professional learning communities communities of continuous inquiry and improvement . Southwest Educational Development Laboratory U.S. Dept. of Education,

Krejcie, R.V. and Morgan, D.W. (1970) Determining Sample Size for Research Activities. Educational and Psychological Measurement, 30, 607-610

Kementerian Pendidikan Malaysia. (2013). Pelan Pembangunan Pendidikan Malaysia 20132025: Pendidikan prasekolah hingga lepas menengah. Putrajaya, Malaysia.

Kruse, S. , Louis, K. S. , \& Bryk, A. (1994). Building professional community in schools. Issues in Restructuring Schools, 6, 3-6.

Louis, K.S., Kruse, S. \& Bryk A.S. (1995), Profesionalism and community: what is it and why is it important in urban schools? dlm. K.S Louis, S. Kruse Associates, 1995. Professionalism and community: Perspectives on Dlm. reforming Urban School. Long Oaks, CA: Corwin.

Nolan (2009). A study of the relationship of teachers' self-efficacy and the impact of professional learning community as an organizational structure. Louisiana: Louisiana Tech University. 
Novita, Kennedy, Mudrika Alamsyah Hasan. (2018). Pengaruh kualitas sumber daya manusia, pengawasan intern dan sistem informasi pengelolaan keuangan daerah terhadap kinerja organisasi perangkat daerah. Jurnal Online Mahasiswa, 1(1), 1-12. Retrieved from https://jom.unri.ac.id/index.php/JOMFEKON/article/view/21571

Scherer, M. (2009), Engaging the Whole Child: Reflections on Best Practices in Learning, Teaching, and Leadership . ASCD

Senge, P.M. (1990), The Leader's New Work: Building Learning Organizations. Harvard Business School

Stegall, D.A. (2011). Professional learning communities and teacher efficacy: A correlational study. Unpublished dissertation, University of North Carolina.

Zuraidah A. 2010. Pembentukan Profil Komuniti Pembelajaran Profesional Sekolah Menengah Di Malaysia. Tesis Ph.D. Institut Pengajian Kepengetuaan, Universiti Malaya. (Unpublished thesis)

Zuraidah Abdullah, Rahimah Hj. Ahmad \& Muhd. Faizal Ab. Ghani (2009). Komuniti pembelajaran profesional dalam kalangan warga sekolah menengah di Malaysia. Universiti Teknologi Malaysia. 